\title{
ПРОБЛЕМЫ АВТОМАТИЗАЦИИ УЧЕТА ПО МСФО
}

\author{
(c) 2020 Антонова Ольга Витальевна \\ кандидат экономических наук, доцент Департамента учета, анализа и аудита \\ Финансовый университет при Правительстве Российской Федерации, Россия, Москва \\ E-mail: olgavit01@yandex.ru
}

На сегодняшний день весомой проблемой как для кредитных организаций, так и для коммерческих организаций является применение международных стандартов финансовой отчетности и в особенности вопросы первого применения. Актуальность данной статьи обуславливается тем, что в последние годы исследований, научных и практических трудов по данной проблеме сравнительно немного, несмотря на серьезность этого вопроса.

Ключевые слова: бухгалтерский учет, отчетность, МСФО, первое применение МСФО, автоматизация

На сегодняшний день наряду с национальными стандартами бухгалтерского учета, многие предприятия применяют международные стандарты финансовой отчетности. Обычно учет по национальным стандартам является первичным. То есть переход к международным стандартам делается либо на основании учета, либо на основании отчетности, полученной из системы бухгалтерского учета по российским стандартам. Международные стандарты, в отличие от российских жестко не регламентируют ведение учета, а часто отдают право принятия учетных решений специалисту, ведущему учет, ссылаясь на профессиональное суждение. Такая «свобода действий» не только ставит в тупик бухгалтера, привыкшего следовать четким инструкциям, но также накладывает свои сложности с точки зрения автоматизации ведения учета по МСФО. Также национальные стандарты в сферу своей регламентированности способствуют одинаковому или очень похожему бухгалтерскому учету почти на всех коммерческих предприятиях, которые отличаются лишь согласно сфере своей деятельности, а учет по международным стандартам в силу рассмотренных особенностей делает каждое предприятие относительно уникальным.

Рассмотрим некоторые особенности информационной системы, автоматизирующей ведение бухгалтерского учета по национальным и международным стандартам, методом параллельного учета на примере реального внедрения.

Параллельный учет ведется с помощью следующих решений, применяемых в информационной системе:

- для системы МСФО применяется свой план счетов;

- на этапе настройки системы создается таблица соответствия счетов РСБУ счетам МСФО;

- записи в системе бухгалтерского учета по РСБУ и МСФО делаются одним электронным документом;

- учет основных средств и нематериальных активов ведется в системе МСФО отдельно, с использованием специальных электронных документов;

- регламентные операции по закрытию месяца в бухгалтерском учете по РСБУ не отражаются в МСФО.

В системе имеется типовой план счетов МСФО, который может быть изменен в соответствии с требованием организации.

Таблица соответствия счетов РСБУ счетам МСФО может строиться как для отдельных счетов по дебету и кредиту, так и для проводки с указанием обоих счетов. Соответствие строится не только на основании синтетических счетов, но и также на основании аналитик, открытых к счетам. Например, для счета 44.01 открыта аналитика статья затрат. Для каждой заведенной статьи этого счета проставлено соответствие.

Также программное решение предусматривает простановку соответствия в зависимости от реквизита аналитики, например для субсчетов счетов $60,62,76$, счета МСФО устанавливаются в зависимости от реквизита «Вид деятельности» договора, который входит в аналитику указанных российских счетов.

При проведении электронного документа создаются проводки в системе РСБУ, после чего 
Таблица 1. Фрагмент таблицы соответствия счета 44.01

\begin{tabular}{|c|c|c|}
\hline \multirow{2}{*}{ Счет хозрасчетный } & Аналитика & \multirow{2}{*}{ Счет международный } \\
\hline & Вид движения & \\
\hline 44.01 & Расходы на прочие затраты по офису (вода, чай, кофе) & \multirow{2}{*}{$\begin{array}{l}660000 \\
\text { Supplies }\end{array}$} \\
\hline Дебет & & \\
\hline 44.01 & Расходы на прочие затраты по офису (вода, чай, кофе) & \multirow{2}{*}{$\begin{array}{l}660000 \\
\text { Supplies }\end{array}$} \\
\hline Кредит & & \\
\hline 44.01 & Прочие расходы (такси) & \multirow{2}{*}{\begin{tabular}{|l}
610090 \\
Other Travel \& \\
Entertainment Expenses
\end{tabular}} \\
\hline Дебет & & \\
\hline 44.01 & Прочие расходы (такси) & \multirow{2}{*}{\begin{tabular}{|l}
610090 \\
Other Travel \& \\
Entertainment Expenses
\end{tabular}} \\
\hline Кредит & & \\
\hline 44.01 & Без лимита принимаемые & \multirow{2}{*}{\begin{tabular}{|l}
610090 \\
Other Travel \& \\
Entertainment Expenses
\end{tabular}} \\
\hline Кредит & & \\
\hline 44.01 & Без лимита принимаемые & \multirow{2}{*}{$\begin{array}{l}610090 \\
\text { Other Travel \& } \\
\text { Entertainment Expenses }\end{array}$} \\
\hline Дебет & & \\
\hline
\end{tabular}

Таблица 2. Фрагмент таблицы соответствий счета 60.02

\begin{tabular}{|c|c|c|}
\hline Счет хозрасчетный & \multirow{2}{*}{ Счет международный } & Реквизит \\
\hline Вид движения & & Значение \\
\hline 60.02 & \multirow{2}{*}{$\begin{array}{l}120000 \\
\text { Trade Receivables }\end{array}$} & Договоры/Вид деятельности \\
\hline Дебет & & Основная \\
\hline 60.02 & \multirow{2}{*}{$\begin{array}{l}120000 \\
\text { Trade Receivables }\end{array}$} & Договоры/Вид деятельности \\
\hline Кредит & & Основная \\
\hline 60.02 & \multirow{2}{*}{$\begin{array}{l}150042 \\
\text { Ppd Operating Exp }\end{array}$} & Договоры/Вид деятельности \\
\hline Дебет & & Неосновная \\
\hline 60.02 & \multirow{2}{*}{$\begin{array}{l}150042 \\
\text { Ppd Operating Exp }\end{array}$} & Договоры/Вид деятельности \\
\hline Кредит & & Неосновная \\
\hline
\end{tabular}

запускается механизм переноса проводок в систему МСФО.

Из-за разницы в российских и международных стандартах учет основных средств и нематериальных активов в программе ведется раздельно, что позволяет применять к основным средствам различные стандарты в принятие, амортизации, переоценки и т.д.

Трудности, возникшие в ходе внедрения можно разделить на три группы:

1. социальные, связанные со взаимодействием с людьми - сотрудниками автоматизируемой организации (сопротивление переменам, негативное отношение к новой информацион- ной системе, снижение эффективности работы во время внедрения);

2. технические, связанные с технической стороной проекта;

3. учетные, связанные непосредственно с отражением фактов хозяйственной деятельности в бухгалтерской информационнотехнической системе по российским стандартам и по МСФО.

Возникшие учетные сложности на стыке двух систем РСБУ и МСФО рассмотрим подробнее. Выделим и опишем следующие проблемы:

- Закрытие периода в МСФО;

- Операции над немонетарными статьями; 
Закрытие периода в МСФО. Одним из требований технического задания был запрет изменения движений в системе МСФО согласно периодам финансового календаря. Сложность заключалась в том, что «российские бухгалтеры» должны были иметь возможность изменять существующие и вводить новые электронные документы. Было принято решение доработать типовой функционал внесением следующих особенностей:

Если электронный документ вводится датой входящей в закрытый период, то бухгалтерские проводки в системе РСБУ относятся на дату документа, а движения МСФО проводятся датой следующей за датой закрытия.

Если документ, относящийся к закрытому периоду МСФО, изменяется, то проводки РСБУ изменяются согласно новым данным документа, проводки МСФО, попадающие в закрытый период, остаются неизменными. Но на дату, следующую за датой закрытия периода МСФО, создаются проводки, сторнирующие старые и проводки, содержащие новые данные.

Операции над немонетарными статьями. Согласно закону о бухгалтерском учете валютой ведения национального учета является россий- ский рубль. Функциональной валютой МСФО является евро.

На каждую отчетную дату монетарные статьи баланса должны отражаться по курсу на отчетную дату, а немонетарные - по курсу на дату совершения операции или дату переоценки, если их учет ведется по справедливой стоимости.

Переоценка монетарных статей осуществляется специальной регламентной операцией в системе. Счета, относящиеся к немонетарным статьям баланса переоцениваться не должны. Для решения задачи в системе существует механизм партионного учета по МСФО, который помимо записей движений в системах РСБУ и МСФО делает записи в дополнительных внутренних таблицах, сохраняя при этом партию из которой возможно получить исторический курс.

С появлением новых видов учета, появляются новые виды программного обеспечения, позволяющие автоматизировать рутинные операции. Информационная система, автоматизирующая учет по международным стандартам, должна быть более универсальной, а значит, необходима как более трудоемкая настройка со стороны организации-внедренца, так и более осознанная работа со стороны пользователя.

\section{Библиографический список}

1. Петров А.М., Полоус Е.А. Повышение транспарентности показателя дебиторской задолженности в отчетности / Международный бухгалтерский учет. 2011. № 6 (156). С. 2-12.

2. Петров А.М., Лымарь М.П. Сравнительная характеристика основных положений законов, регулирующих бухгалтерский учет в Китае и России / Международный бухгалтерский учет. 2013. № 40 (286). С. 52-60.

3. Петров А.М. Контроль за движением дебиторской и кредиторской задолженности / Современный бухучет. 2004. № 9. С. 38.

4. Бабаев Ю.А., Друцикая М.В., Кеворкова Ж.А., Листопад Е.Е., Петров А.М. Бухгалтерский учет, анализ и аудит внешнеэкономической деятельности. Учебник для студентов обучающихся по специальности 080109 «Бухгалтерский учет, анализ и аудит» / под редакцией Ю.А. Бабаева. Москва, 2010.

5. Петров А.М., Мельникова Л.А. Теоретические аспекты учета калькулирования себестоимости продукции / Экономические науки. 2013. № 102. С. 145-148.

6. Петров А.М., Коняхин А.Н. Учетная политика при подготовке первой отчетности согласно МСФО / Международный бухгалтерский учет. 2013. № 11 (257). С. 2-15.

7. Бабаева З.Д., Гетьман В.Г., Гришкина С.Н., Домбровская Е.Н., Керимов В.Э., Неселовская Т.М., Рожнова О.В., Сиднева В.П., Петров А.М., Блинова У.Ю. Бухгалтерский учет. Учебник / Москва, 2017. Сер. Бакалавриат (2-е издание, переработанное и дополненное)

8. Петров А.М. Актуальные вопросы экономико-правового регулирования и классификации корпоративных систем / Проблемы современной экономики. 2009. № 1 (29). С. 182-186.

9. Петров А.М., Мельникова Л.А. Формирование отчетности в соответствии с требованиями МСФО как объективная необходимость на современном этапе развития экономики РФ / Проблемы современной экономики. 2017. № 2 (62). С. 105-107.

10. Петров А.М. Общественное питание 6 в 1: учетная политика, документооборот, калькулирование себестоимости, бухгалтерский учет, налоги, отчетность / А.М. Петров. Москва, 2011. Сер. Полное руководство бухгалтера 
11. Петров А.М. Бухгалтерский учет основных средств / Бухгалтерский учет в издательстве и полиграфии. 2012. № 3 (159). C. 2-22.

12. Петров А.М., Лымарь М.П. Сравнительная характеристика основных положений законов, регулирующих бухгалтерский учет в Китае и России / Все для бухгалтера. 2014. № 1 (277). С. 36-43. 